\title{
Prevalence of Serologic Markers and Risk Factors for Hepatitis B Virus among Pregnant Women in Brazzaville, Congo
}

\author{
Brunel Monic ANGOUNDA ${ }^{1,2,3}$, Amélia BOKILO DZIA ${ }^{1,4}$, Luc Magloire Anicet BOUMBA ${ }^{3}$, Clotaire \\ ITOUA $^{4,5}$, Gabriel AHOMBO $^{2}$, Donatien MOUKASSA ${ }^{4}$, Jean-Rosaire IBARA ${ }^{3}$, Moulay Mustapha \\ ENNAJI $^{4^{*}}$
}

${ }^{1}$ Laboratoire du Dépistage des Infections Transmissibles, Centre National de Transfusion Sanguine.

\begin{abstract}
${ }^{2}$ Laboratoire de Biologie Cellulaire et Moléculaire, Faculté des Sciences et Techniques, Université Marien NGOUABI, Brazzaville, Congo
${ }^{3}$ Laboratoire de Virologie, Microbiologie et Qualité/Eco-toxicologie et biodiversité, Faculté des Sciences et Techniques Mohammedia, Université Hassan II de Casablanca, Maroc
\end{abstract}

${ }^{4}$ Faculté des Sciences de la Santé, Université Marien NGOUABI, Brazzaville, Congo

${ }^{5}$ Service de Gynécologie Obstétrique, CHU de Brazzaville

\begin{abstract}
Background: Viral hepatitis $B$ is widespread globally and fetomaternal infection transmission is a major public health problem. Few studies are available on $\mathrm{HBV}$ vertical transmission infection in Brazzaville. The purpose of this study was to investigate the prevalence of $\mathrm{HBV}$ markers and risk factors in pregnant women. Methods: A cross-sectional study was carried out from January to September 2014 among pregnant women attending antenatal clinics in Brazzaville. Relevant demographics and infectious risk factors were obtained. HBV serological markers were evaluated for $\mathrm{HBsAg}, \mathrm{HBeAg}$, anti-HBe, anti-HBs, anti-HBc using an enzyme-linked immunosorbent assay. Results: Of a total of 437 women tested, 38 were positive for $\mathrm{HBsAg}(8.7 \%), 15$ (3.4\%) $\mathrm{HBeAg}$, and 41 (9.4\%) for AcHBe. The anti-HBs and anti-HBc were positive in $96(22 \%)$ and $287(65.7 \%)$ cases respectively. The main significant risk factors were: piercings (adjusted $O R=3.16,95 \%$ CI: $1.48-6.73$ ), risky sexual behavior (AOR $=45.32,95 \%$ CI: 3.22 to 638.47), family history $(A O R=2.17,95 \%$ CI: 1.07-4.12) and scarification (AOR = 3.84, 95\% CI: 1.53-9.66). Conclusion: Our results show a high frequency of $H B V$ infection markers in pregnant women in Brazzaville. Screening for $\mathrm{HBV}$ and systematic implementation of vaccination programs should be considered in pregnant women to prevent $\mathrm{HBV}$ vertical transmission.
\end{abstract}

Keywords: Hepatitis B virus, markers, risk factors, pregnant women, Brazzaville

\section{Introduction}

Hepatitis B is a leading cause of chronic infection worldwide, with over 350 million people chronically infected and about 600.000 people die each year [1]. Global prevalence of Hepatitis $B$ virus (HBV) infection is distributed in three areas in the world of high $(\geq 8 \%)$, intermediate $(2-7 \%)$ and low $(<2 \%)$ [2]. In the Republic of Congo, the prevalence of $\mathrm{HBsAg}$ is high, with rates oscillating between $6.5 \%$ to $17 \%$ in the general population and depending on the departments [3-6].

Hepatitis B virus (HBV) has clinical and obstetrics significance due to the fact that HBV during pregnancy is not only associated with the high risk of maternal complications but also a high rate of vertical transmission causing fetal and neonatal hepatitis [7]. This perinatal transmission of HBV causes serious long-term sequelae among children [8]. Children born to seropositive mothers for the surface antigen of hepatitis B (HBsAg) and hepatitis $\mathrm{B}$ e antigen (HBeAg) have between 70 to $90 \%$ of perinatal risk of acquiring infection by HBV. However, $85-90 \%$ of them end up becoming chronic carriers of the disease; in contrast to risk of $10-40 \%$ in infants born to mothers who are $\mathrm{HBsAg}$ positive but negative for $\mathrm{HBeAg}[9,10]$.
A chronic HBV carrier have an increased risk of life to die from hepatocellular carcinoma and liver cirrhosis (25\% risk) and continues to remain the main reservoir of $\mathrm{HBV}$ transmission [11]. Some of them eventually become mothers themselves, perpetuating the cycle [12]. Many recent data are available on the epidemiology of HBV in pregnant women and evaluation of perinatal transmission in different countries in Africa [13, 14]. However, few data on HBV carrying markers are available from Congo those existing are old [5].

Since HBV leads to serious consequences, it is important that epidemiology should be reviewed continuously. This study was conducted in Brazzaville, Republic of Congo, to investigate the prevalence and risk factors for HBV markers in pregnant women in order to target preventive measures.

\section{Methods}

\subsection{Study Design and Setting}

This study was conducted in Brazzaville, the administrative capital city of the Republic of Congo. A cross-sectional study was carried out from January to September 2014 among pregnant women attending antenatal clinics. It concerned health center BISSITA, Jeanne Vialle, Marien Ngouabi and CHU of Brazzaville. The choice of these 


\section{International Journal of Science and Research (IJSR) ISSN (Online): 2319-7064 \\ Index Copernicus Value (2013): 6.14 | Impact Factor (2014): 5.611}

different centers was made according to the geographical location.

\subsection{Study Population}

We included women with confirmed pregnancy that provided written informed consent to participate in the study. Pregnancy was confirmed by one of the following means: positive pregnancy test (urine or serum B-HCG); Ultrasound: invigorating; and the presence of fetal heart. After obtaining signed informed consent of participants in the study, relevant demographics and infectious risk factors were obtained through anonymous questionnaires completed by trained midwives.

HBV serological markers were evaluated for $\mathrm{HBsAg}$, hepatitis $\mathrm{B}$ e antigen ( $\mathrm{HBeAg})$, antibody against hepatitis B e antigen (anti-HBe), hepatitis B surface antibody (anti-HBs) and hepatitis B core antibody (anti-HBc). We used a commercial enzyme-linked immunosorbent assay (ELISA) kit (Bio-Rad Laboratories, Marnes La Coquette, France) according to the manufacturer's instructions.

\subsection{Statistical Analysis}

The data were organized and analyzed using the Epi-Info program, version 7.0. In the bivariate analysis explanatory variables with $p$-value less than or equal to 0.2 were included in a logistic regression. Odds ratio (OR) and their $95 \%$ confidence intervals $(\mathrm{CI})$ were calculated. The results were considered statistically significant at $\mathrm{p}<0.05$.

\subsection{Ethical Considerations}

Each participant signed a consent letter at the beginning of the investigation and had the opportunity to stop participating at any stage of the process. All results were returned to the subjects, and participants who were detected as HBs antigen carriers were referred to specialists for treatments. The study was approved by the local ethics committee on research in the health sciences in Congo.

\section{Results}

A total of 437 pregnant women were included. The mean age of women was 29.31 \pm 7.67 years (range 15-45 years), medium-term pregnancy was $21.49 \pm 13.31$ weeks of amenorrhea and the average parity of $1.25 \pm 1.35$ (range $0-5$ parities).

Out of the 437 women tested, 38 were positive for HBsAg (8.7\%; 95\% CI: $6.30-11.84), 15$ for HBeAg (3.4\%; 95\% CI: 2.00-5.73), and 41 for AcHBe (9.4\%; 95\% CI: 6.86-12.61). Search for $\mathrm{HBsAb}$ and $\mathrm{AcHBc}$ were positive in $96(22 \%$; 95\% CI: 18.23-26.21) and $287(65.7 \%$; 95\% CI: 60.9970.08 ) cases respectively (Table 1$)$.

All results of univariate analysis of socio-demographic characteristics or risk factors for viral transmission are summarized in Table 2. Our finding showed that, the frequencies of all studied markers were high in younger women aged than lower 30 years, in multiparity and married; however_no significant differences were found between these variables and HBV infection $(p>0.05)$.

In add no correlation was found between HBV infections with abortion, tattoos, history of surgery and dental surgery. In univariate and multivariate analyzes wearing piercings (adjusted OR $=3.16,95 \% \mathrm{CI}: 1.48-6.73$ ), risky sexual behavior (adjusted OR $=45.32,95 \%$ CI: 3.22 to 638.47 ), family history (adjusted OR $=2.17 .95 \% \mathrm{CI}: 1.07-4.12$ ) and scarification (adjusted OR $=3.84,95 \% \mathrm{CI}$ : $1.53-9.66$ ) were significant risk factors $(\mathrm{p}<0.05)$ (Table 3$)$.

\section{Discussion}

Brazzaville, capital city presents a socio-cultural diversity of the country and the number of immigrants is very high. The prevalence of HBV markers was very important in the population of pregnant women in Brazzaville, 78.3\% (342) women had at least one marker of HBV. This is similar to the study made by Itoua-Ngaporo et al. with HBV carrying $57.8 \%$ among pregnant women in Brazzaville [5]. This data confirms that the Congo is countries with high prevalence of HBV country and high risk of vertical transmission [2].

The prevalence of HBsAg was $8.7 \%$, high prevalences were observed in similar studies, $8.0 \%$ in Mali [10], 9.6\% in Republic of Congo [6], $16.6 \%$ in Niger [15] and lower prevalences were observed in Ethiopia [16] with 3.2\% and $5.6 \%$ in Sudan [17].

Anti-HBc was detected in $208(65.7 \%)$ pregnant women similar prevalences high were observed in Brazzaville with $57.8 \%$ [18] ; 81.6\% in Cote d'Ivoire [19], 61\% in Zimbabwe [20] and lower, 5\% in Spain [21]; 33\% South Africa [22]. Geographical differences, local epidemiology, cultural practices including contamination at a very early in life may explain the variation in HBV prevalence of these markers in pregnant women from different countries.

In our series, $3.4 \%$ of women positive for $\mathrm{HBeAg}$, low prevalences were also detected in HBsAg positive pregnant women in some countries, in Ethiopia $(<1 \%)$ [23], Nigeria $(1.39 \%)[24]$ and by against the highest prevalences were found in other parts of South and Southeast Asia, where prevalence of $\mathrm{HBeAg}$ varies $15 \%-88 \%$ is reported in young women $[11,25,26]$. This difference was largely due to the natural history of HBV infection in Southeast Asia where infected individuals carry $\mathrm{HBeAg}$ and high viral load in the age groups that include most of the gestational age women $[7,27]$. The risk of transmission of HBV from mother to child depends on the importance of viral replication. It has been estimated at more than $90-100 \%$ if $\mathrm{HBe}$ antigen (HBeAg) is detected in maternal serum. The presence of $\mathrm{HBeAg}$ was also associated with a high risk of failure in neonatal prevention [9]. However, even in the absence of $\mathrm{HBeAg}, \mathrm{HBV}$ transmission risk exists and interpretation of the absence of $\mathrm{HBeAg}$ must consider the possibility of viral replication in asymptomatic carriers and at viral gene mutation $\mathrm{C}$, high viremia then being possible [28, 29].

In this study, the prevalence of markers was majority among women 30 years with $40 \%$ and the different age groups were less significant, similar results were found in Nigeria and 


\section{International Journal of Science and Research (IJSR) \\ ISSN (Online): 2319-7064 \\ Index Copernicus Value (2013): 6.14 | Impact Factor (2014): 5.611}

Yemen [30, 31]. Many studies confirm the high rate of infection at birth or during early childhood especially in high prevalence areas $[9,11]$.

During this work no link was observed in porting markers with parity, marital status, occupation, education, a history of abortions and blood transfusion. Some studies report a link between abortions as risk factors and multiparous women may be more at risk than nulliparous women $[9,32$, 33]. In part, this may be due to the increasing adoption of universal precautions by medical staff because of pandemics $\mathrm{HCV}, \mathrm{HIV}$, in which all patients are treated as potentially infectious and therefore precautions are taken to minimize the risk of transmission because they share similar modes of transmission [12, 33] .Blood transfusion was not a significant risk factor for $\mathrm{HBV}$, because $\mathrm{HBV}$ testing is performed in all blood donors and excluding those testing positive [16]

HBV is transmitted through blood and other body fluids, including semen and saliva. HBV is present in all body fluids, we found a link between the carriage of different markers in the family antecedent $(\mathrm{OR}=2.17 .95 \% \mathrm{CI}: 1,07$ 4.12), percing (OR=3.16, 95\%CI:1.48-6.73), scarification $(\mathrm{OR}=3.84,95 \% \mathrm{CI}: 1.53-9.66)$, multiple partners $(\mathrm{OR}=45.32$, $95 \% \mathrm{CI}: 3,22-638,47)$. These data are similar to studies conducted in Ethiopia [9, 16, 34]. Sexual transmission has long been recognized as a major source of HBV transmission in all regions of the world [35-37]. This high prevalence of markers suggests that vertical transmission may be a very important means of transmission of $\mathrm{HBV}$, the inclusion of newborn was ideal.

\section{Conclusion}

The prevalence of serological markers of hepatitis B was higher in our study, which confirms the high risk of perinatal transmission. Thus, strategies must be developed to prevent this, including routine screening of pregnant women and the implementation of vaccination programs for newborns. Future studies are desirable to assess the situation at national level.

\section{Competing Interests}

The authors declare that they have no competing interests.

\section{Authors' Contributions}

Study conception and design: BMA, DM, CI, ABD, JRI. Data acquisition: BMA, CI. Data analysis and interpretation: BMA, LMAB, GA, CI, ABD. Critical discussion and manuscript revision: BMA, LMAB, DM, CI, ABD, JRI, GA, MME. All the authors approved the final version of the manuscript.

\section{Acknowledgements}

We are grateful to all the pregnant women who participated in this research and staff of CSI: Bissita, Jeanne Vialle, Marien Ngouabi and University Hospital of Brazzaville. The study was entirely financed by personal funds of BMA and $\mathrm{ABD}$, with no external funding source.

\section{References}

[1] Hwang EW, Cheung R. Global epidemiology of hepatitis B virus (HBV) infection. N Am J Med Sci. 2011;4(1):7-13.

[2] World Health Organization. Hepatitis B vaccines. Wkly Epidemiol Rec. 2009;40:405-420.

[3] Makuwa M, Ngoli D, Jannin J, Moulia Pelat JP. Marqueurs sérologiques du virus de l'hépatite B et du virus VIH dans la zone semi-rurale et rurale congolaise. Med d'Afr. Noire. 1992;39(12):790-791.

[4] Makuwa M, Bakouetela J, Bassindikila A, SambaLefebvre MC. Etude des marqueurs sérologiques de l'hépatite $\mathrm{B}$ chez les patients congolais testés pour l'infection à VIH. Med d'Afr. Noire. 1996;43(4):198200.

[5] Itoua-Ngaporo A, Gbala Sapoulou M V, Ibara JR, Iloki LH, Denis F. Prévalence des marqueurs du virus de l'hépatite $\mathrm{B}$ dans une population de femmes enceintes à Brazzaville (Congo). J Gynecol Obstet Biol Reprod. 1995;24(24):534-536.

[6] Bossali F, Taty-Taty R, Houssissa P, N'suele W, Lingouala LG, Ontsira EN. Séroprévalence de la coinfection hépatite $\mathrm{B}$, hépatite $\mathrm{C}$ et VIH chez des femmes accouchées à la maternité de l'hôpital Adolphe Sicé de Pointe-Noire en 2010. J. Afr. Hépatol. Gastroentérol. 2012;6(4):315-319.

[7] Sinha S, Kumar M. Pregnancy and chronic hepatitis B virus infection. Hepatol Res. 2010; 40(1):31-48.

[8] Krajden M, McNabb G, Petric M. The laboratory diagnosis of hepatitis B virus. Can J Infect Dis Med Microbiol. 2005;16(2):65.

[9] Tegegne D, Desta K, Tegbaru B, Tilahun T. Seroprevalence and transmission of Hepatitis B virus among delivering women and their new born in selected health facilities, Addis Ababa, Ethiopia: a cross sectional study. BMC Res Notes. 2014;7(1):239.

[10] MacLean B, Hess RF, Bonvillain E, Kamate J, Dao D, Cosimano A, Hoy S. Seroprevalence of hepatitis B surface antigen among pregnant women attending the Hospital for Women \& Children in Koutiala, Mali. S Afr Med J. 2012;102(1):47-49.

[11]Ding Y, Sheng, Q, Ma L, Dou X. Chronic HBV infection among pregnant women and their infants in Shenyang, China. Virol J. 2013;10(17):1-5.

[12] Howell J, Lemoine M, Thursz M. Prevention of materno-foetal transmission of hepatitis B in subSaharan Africa: the evidence, current practice and future challenges. J Viral Hepat. 2014;21(6):381-396.

[13] Sidibe S, Sacko B, Traore I. Prevalence of serologic markers of the hepatitis B virus in pregnant women of Bamako, Mali. Bull Soc Pathol Exot. 2001;94(4):339341.

[14] Kramvis A, Kew MC. Epidemiology of hepatitis B virus in Africa, its genotypes and clinical associations of genotypes. Hepatol Res. 2007;37(1):9-19.

[15] Mamadou S, Ide M, Maazou ARA, Aoula B, Labo S, Bozari M. HIV infection and hepatitis B seroprevalence among antenatal clinic attendees in Niger, West Africa. HIV/AIDS (Auckland, NZ). 2012;4:1. 


\section{International Journal of Science and Research (IJSR) \\ ISSN (Online): 2319-7064 \\ Index Copernicus Value (2013): 6.14 | Impact Factor (2014): 5.611}

[16]Zenebe Y, Mulu W, Yimer M, Abera B. Seroprevalence and risk factors of hepatitis $\mathrm{B}$ virus and human immunodeficiency virus infection among pregnant women in Bahir Dar city, Northwest Ethiopia: a cross sectional study. BMC Infect Dis. 2014;14(1): 118 .

[17]Elsheikh RM, Daak AA, Elsheikh MA, Karsany MS, Adam I. Hepatitis B virus and hepatitis $\mathrm{C}$ virus in pregnant Sudanese women. Virol J. 2007;4:104.

[18] Itoua-Ngaporo A, Sapoulou M, Ibara J, Iloki L, Denis F. Prevalence of hepatitis B viral markers in a population of pregnant women in Brazzaville (Congo). J Gynecol Obstet Biol Reprod. 1994;24(5):534-536.

[19] Combe P, La Ruche G, Bonard D, Ouassa T, Faye-Ketté $\mathrm{H}$, Sylla-Koko F, et al. Hepatitis B and C infections, human immunodeficiency virus and other sexually transmitted infections among women of childbearing age in Côte d'Ivoire, West Africa. Trans R Soc Trop Med Hyg. 2001;95(5):493-496.

[20] Madzime S, Adem M, Mahomed K, Woelk GB, Mudzamiri S, Williams MA. Hepatitis B virus infection among pregnant women delivering at Harare Maternity Hospital, Harare Zimbabwe, 1996 to 1997. Cent Afr J Med. 1999;45(8).

[21] Salleras L, Dominguez A, Bruguera M, Plans P, Espunes J, Costa J, et al. Seroepidemiology of hepatitis $B$ virus infection in pregnant women in Catalonia (Spain). J Clin Virol. 2009;44(4):329-332.

[22] Andersson M, Maponga T, Ijaz S, Barnes J, Theron G, Meredith S, et al. The epidemiology of hepatitis B virus infection in HIV-infected and HIV-uninfected pregnant women in the Western Cape, South Africa. Vaccine. 2013;31(47):5579-5584.

[23] Abebe A, Nokes DJ, Dejene A, Enquselassie F, Messele T, Cutts F. Seroepidemiology of hepatitis B virus in Addis Ababa, Ethiopia: transmission patterns and vaccine control. Epidemiol Infect. 2003;131(01):757770.

[24] Harry TO, Bajani M, Moses A. Hepatitis B virus infection among blood donors and pregnant women in Maiduguri, Nigeria. East Afr Med J. 1994;71(9):596597.

[25] Ott J, Stevens G, Groeger J, Wiersma S. Global epidemiology of hepatitis B virus infection: new estimates of age-specific HBsAg seroprevalence and endemicity. Vaccine. 2012;30(12):2212-2219.

[26]Zhang X, Xing Y, Shen L. [Follow-up on hepatitis B immunized neonates born to HBsAg positive mothers]. Zhonghua yu fang yi xue za zhi [Chinese journal of preventive medicine]. 1998;32(2):97-99.

[27] Kao JH, Chen PJ, Lai MY, Chen DS. Clinical and virological aspects of blood donors infected with hepatitis B virus genotypes B and C. J Clin Microbiol. 2002;40(1):22-25.

[28] Sangfelt P, Von Sydow M, Uhnoo I, Weiland O, Lindh $\mathrm{G}$, Fischler B, et al. Serum ALT levels as a surrogate marker for serum HBV DNA levels in $\mathrm{HBeAg-negative}$ pregnant women. Scand J Infect Dis. 2004;36(3):182185.

[29] Elefsiniotis IS, Glynou I, Magaziotou I, Pantazis KD, Fotos NV, Brokalaki $\mathrm{H}$, et al. $\mathrm{HBeAg}$ negative serological status and low viral replication levels characterize chronic hepatitis B virus-infected women at reproductive age in Greece: a one-year prospective single center study. World J Gastroenterol. 2005;11(31):4879-4882.

[30] Musa BM, Bussell S, Borodo MM, Samaila AA, Femi OL. Prevalence of hepatitis B virus infection in Nigeria, 2000-2013: a systematic review and meta-analysis. Niger J Clin Pract. 2015;18(2):163-172.

[31]Al-Shamahy H. Prevalence of hepatitis B surface antigen and risk factors of $\mathrm{HBV}$ infection in a sample of healthy mothers and their infants in Sana'a, Yemen. Ann Saudi Med. 2000;20(5/6):464-466.

[32] Dwivedi M, Misra SP, Misra V, Pandey A, Pant S, Singh R, et al. Seroprevalence of hepatitis B infection during pregnancy and risk of perinatal transmission. Indian J Gastroenterol. 2011;30(2):66-71.

[33] Eke AC, Eke UA, Okafor CI, Ezebialu IU, Ogbuagu C. Prevalence, correlates and pattern of hepatitis B surface antigen in a low resource setting. Virol J. 2011;8:12.

[34] Pungpapong S, Kim WR, Poterucha JJ. Natural history of hepatitis B virus infection: an update for clinicians. In: Mayo Clinic proceedings. Elsevier. 2007;82(8):967975.

[35] Rabiu KA, Akinola OI, Adewunmi AA, Omololu OM, Ojo TO. Risk factors for hepatitis B virus infection among pregnant women in Lagos, Nigeria. Acta Obstet Gynecol Scand. 2010;89(8):1024-1028.

[36] Ogunkunle M, Oni A, Odaibo G, Olaleye O. Hepatitis B surface antigen ( $\mathrm{HbsAg}$ ) in blood and genital secretions of patients with sexually transmitted diseases in Ibadan, Nigeria. West Afr J Med. 2006;24(3):206-208.

[37] Murad EA, Babiker SM, Gasim GI, Rayis DA, Adam I. Epidemiology of hepatitis $\mathrm{B}$ and hepatitis $\mathrm{C}$ virus infections in pregnant women in Sana'a, Yemen. BMC Pregnancy Childbirth. 2013;13(1):127.

Table 1: Prevalence of hepatitis B markers detected in Pregnant women in Brazzaville, Congo 2014 ( $n=437)$.

\begin{tabular}{cccc}
\hline $\begin{array}{c}\text { Serological } \\
\text { markers }\end{array}$ & $\mathrm{n}$ & $\%$ & $95 \% \mathrm{Cl}$ \\
\hline $\mathrm{HBsAg}$ & 38 & 8.7 & $6.30-11.84$ \\
$\mathrm{HBeAg}$ & 15 & 3.4 & $2.00-5.73$ \\
Anti-HBe & 41 & 9.4 & $6.86-12.61$ \\
Anti-HBs & 96 & 22 & $18.23-26.21$ \\
Anti-HBc & 287 & 65.7 & $60.99-70.08$ \\
\hline
\end{tabular}




\section{International Journal of Science and Research (IJSR) \\ ISSN (Online): 2319-7064 \\ Index Copernicus Value (2013): 6.14 | Impact Factor (2014): 5.611}

Table 2: Characteristics and their relation to the prevalence of HBV serological markers among pregnant women in

Brazzaville, Congo $2014(\mathrm{n}=437)$

\begin{tabular}{|c|c|c|c|c|}
\hline Characteristics & HBV +ve & HBV -ve & OR $(95 \% \mathrm{Cl})$ & P-value \\
\hline \multicolumn{5}{|l|}{ Age } \\
\hline $15-20$ & $68(19.9)$ & $29(30.5)$ & $0.85(0.37-1.98)$ & 0.712 \\
\hline $21-30$ & $160(46.8)$ & $38(40.0)$ & $0.48(0.21-1.06)$ & 0.070 \\
\hline $31-40$ & $92(26.9)$ & $17(17.9)$ & $0.37(0.15-0.89)$ & 0.028 \\
\hline $40-45$ & $22(6.4)$ & $11(11.6)$ & 1 (Reference) & \\
\hline \multicolumn{5}{|l|}{ Pregnancy stage } \\
\hline $1^{\circ}$ trimester & $113(33.0)$ & $35(36.8)$ & $0.52(0.27-1,02)$ & 0.061 \\
\hline $2^{\circ}$ trimester & $137(40.1)$ & $45(47.4)$ & $1.06(0.64-1.76)$ & 0.821 \\
\hline $3^{\circ}$ trimester & $92(26.9)$ & $15(15.8)$ & 1 (Reference) & \\
\hline \multicolumn{5}{|l|}{ Parité } \\
\hline Primiparity & $122(35.7))$ & $37(38.9)$ & $1.15(0.72-1.84)$ & 0.641 \\
\hline Multiparity & $220(64.3)$ & $58(61.1)$ & 1 (Reference) & \\
\hline \multicolumn{5}{|l|}{ Education } \\
\hline University & $59(17.3)$ & $20(21.1)$ & $1.36(0.51-3.58)$ & 0.539 \\
\hline High & $154(45.0)$ & $35(36.8)$ & $0.91(0.37-2.25)$ & 0.837 \\
\hline Primary & $101(29.5)$ & $33(34.7)$ & $1.31(0.52-3.27)$ & 0.567 \\
\hline No school & $28(8.2)$ & $7(7.4)$ & 1 (Reference) & \\
\hline \multicolumn{5}{|l|}{ Marital status } \\
\hline Married & $200(58.5)$ & $53(55.8)$ & $0.89(0.57-1.42)$ & 0.639 \\
\hline Unmarried & $142(41.5)$ & $42(44.2)$ & 1 (Reference) & \\
\hline \multicolumn{5}{|l|}{ Occupation } \\
\hline student & $73(31.4))$ & $25(26.3)$ & $1.07(0.59-1.92)$ & 0.833 \\
\hline professionnel & $41(11.9)$ & $16(16.8)$ & $1.21(0.61-2.42)$ & 0.581 \\
\hline military & $17(4.9)$ & $4(4.2)$ & $0.73(0.23-2.32)$ & 0.596 \\
\hline laborer & $99(28.9)$ & $14(14.7)$ & $0.44(0.22-0.86)$ & 0.017 \\
\hline unemployed & $112(32.8)$ & $36(37.9)$ & 1 (Reference) & \\
\hline
\end{tabular}

HBV, Hepatitis B virus; OR, odds ratio; -ve, negative; +ve, positive; CI, confidence interval

Table 3: Univariate and multivariate analyses for risk factors of HBV among pregnant women in Brazzaville, Congo 2014

\begin{tabular}{|c|c|c|c|c|c|}
\hline Risks factors & HBV +ve & HBV -ve & COR $(95 \% \mathrm{Cl})$ & AOR (95\%) & P-value \\
\hline \multicolumn{6}{|l|}{ Abortion } \\
\hline Yes & $55(16.1)$ & $15(15.8)$ & $1.02(0.55-1.90)$ & $1.16(0.59-2.27)$ & 0.665 \\
\hline No & $287(83.9)$ & $80(84.2)$ & 1(Reference) & 1 (Reference) & \\
\hline \multicolumn{6}{|c|}{ Blood Transfusion } \\
\hline Yes & $18(5.3)$ & $3(3.2)$ & $1.70(0.49-5.91)$ & $1.58(0.43-5.82)$ & 0.485 \\
\hline No & $324(94.7)$ & $92(96.8)$ & 1(Reference) & 1 (Reference) & \\
\hline \multicolumn{6}{|l|}{ Tattooing } \\
\hline Yes & $14(4.1)$ & $6(6.3)$ & $0.63(0.24-1.69)$ & $0.467(0.07-2.97)$ & 0.421 \\
\hline No & $328(95.9)$ & $89(93.7)$ & 1(Reference) & 1(Reference) & \\
\hline \multicolumn{6}{|c|}{ History of surgery } \\
\hline Yes & $23(6.7)$ & $8(8.4)$ & $0.78(0.34-1.81)$ & $1.31(0.27-6.42)$ & 0.739 \\
\hline No & 319 (93.3) & $87(91.6)$ & 1(Reference) & 1 (Reference) & \\
\hline \multicolumn{6}{|c|}{ Familial antecedent } \\
\hline Yes & $152(44.4)$ & $17(17.9)$ & $3.67(2.08-6.47)$ & $2.17(1.07-4.12)$ & 0.032 \\
\hline No & $190(55.6)$ & $78(82.1)$ & 1(Reference) & 1 (Reference) & \\
\hline \multicolumn{6}{|l|}{ Percing } \\
\hline Yes & $119(34.8)$ & $10(10.5)$ & $4.54(2.27-9.06)$ & $3.16(1.48-6.73)$ & 0.003 \\
\hline No & $223(65.2)$ & $85(89.5)$ & 1(Reference) & 1 (Reference) & \\
\hline \multicolumn{6}{|c|}{ Risky sexual behavior } \\
\hline Yes & $87(24.4)$ & $5(5.3)$ & $6.14(2.42-15.61)$ & $45.32(3.22-638.47)$ & 0.005 \\
\hline No & $255(74.6)$ & $90(94.7)$ & 1(Reference) & 1 (Reference) & \\
\hline \multicolumn{6}{|l|}{ Scarification } \\
\hline Yes & $88(25.7)$ & $7(7.4)$ & $4.36(1.94-9.76)$ & $3.84(1.53-9.66)$ & 0.004 \\
\hline No & $254(74.3)$ & $88(92.6)$ & 1(Reference) & 1 (Reference) & \\
\hline \multicolumn{6}{|c|}{ Dental surgery } \\
\hline Yes & $24(7.0)$ & $7(7.4)$ & $0.949(039-2.27)$ & $1.67(0.46-6.05)$ & 0.432 \\
\hline No & $318(93.0)$ & $88(92.6)$ & 1(Reference) & 1(Reference) & \\
\hline
\end{tabular}

HBV, Hepatitis B Virus; A. OR, Adjusted odds ratio; C. OR, Crude odds ratio; -ve., Negative; +ve, positive. 


\section{International Journal of Science and Research (IJSR) \\ ISSN (Online): 2319-7064}

Index Copernicus Value (2013): 6.14 | Impact Factor (2014): 5.611

\section{Author Profile}

Brunel Monic ANGOUNDA : Graduated in M.Sc. of Molecular Biology and applied immunology to the Faulty of Science and Technology, Brazzaville (University Marien Ngouabi, Republic of the Congo) in 2013. He is currently a PhD student in Virology and Molecular Biology to the FST-BZV (University Marien Ngouabi) in collaboration with the FST- Mohammedia (University of Hassan II Casablanca), Morocco. 